\title{
Analysis of the Impact of Storytelling Methods on Early Childhood Religion and Moral Development
}

\author{
Ni Wayan Rasmini ${ }^{1 凶}$, I Wayan Karta ${ }^{1}$ \\ Pendidikan Guru Pendidikan Anak Usia Dini, Institut Agama Hindu Negeri Gde Pudja \\ Mataram, Indonesia ${ }^{(1)}$ \\ DOI: $10.31004 /$ obsesi.v6i3.1719
}

\begin{abstract}
Kegiatan pengembangan moral dan agama masih perlu digalakkan dalam pembelajaran anak usia dini. Tujuan penelitian ini adalah untuk menganalisis pengaruh metode bercerita terhadap perkembangan agama dan moral anak usia dini. Penelitian ini menggunakan metode kuantitatif dengan pendekatan eksperimen pre-test post-test one group design berlokasi di Taman Kanak-Kanak Cahaya Ananda Mataram yang ditentukan secara porpusive kluster sampling. Subjek penelitian ini sebanyak 52 orang anak sebagai responden dari kelas B1, B2, dan B3. Perlakuan dilakukan empat kali dengan menggunakan metode bercerita dengan alat, boneka tangan, papan planel berdiri, tempel dan buku cerita dengan tema lingkungan. Terdapat peningkatan rata-rata; pengaruh positif penerapan pembelajaran metode bercerita terhadap tumbuh-kembang agama/moral anak usia dini. Disarankan bagi guru pendidikan anak usia dini untuk senantiasa meningkatkan keterampilan bercerita untuk dapat meningkatkan potensi anak, khususnya dalam perkembangan moral dan agama anak usia dini.
\end{abstract}

Kata Kunci: metode bercerita; perkembangan agama dan moral; anak usia dini.

\begin{abstract}
Activities of moral and religious development must also be promoted in preschool education. The purpose of this study was to analyses the impact of the storytelling method on the religious and moral development of early childhood. The study uses a quantitative method with an experimental post-test pre-test approach of a group design located at Cahaya Ananda Preschool, Mataram which is determined by a purposive cluster sampling. The subjects in this study were 52 children surveyed in classes B1, B2 and B3. The treatment was carried out four times using the storytelling method with tools, hand puppets, standing planel boards, paste and story books with environmental themes. There was an average increase; positive influence of the application of the learning method of storytelling on the religious/moral growth of early childhood. It is recommended that early childhood education teachers constantly improve their storytelling skills in order to be able to increase the potential of children, especially in the moral and religious development of early childhood.
\end{abstract}

Keywords: storytelling method; religious and moral development; early childhood.

Copyright (c) 2021 Ni Wayan Rasmini, I Wayan Karta

$\square$ Corresponding author:

Email Address : niwayanrasmini@iahn-gdepudja.ac.id (Mataram, Indonesia)

Received 4 March 2021, Accepted 19 August 2021 tahun, Published 22 August 2021 


\section{INTRODUCTION}

The development of religion and morality has great significance in human life. It would be preferable to inculcate them at a young age, but so far, the topic of learning. The Early Childhood Education Institute failed to provide a specific theme for religious and moral development. The lack of guidance for the organization of learning on religious and moral development results in religious and moral development of early childhood only in habituation activities. After a thorough analysis of the characteristics of early childhood religious and moral development are suitable learning resources for religious and moral development material. There are legends, fables, tales of wayang, and songs.

Religious and moral development includes the ability to recognize religious values, perform worship, behave honestly, be helpful, polite, respectful, sporty, maintain personal and environmental hygiene, know religious holidays, and respect (tolerance) other people's religions (Permendikbud, 2014). Religious and moral development activities for early childhood are carried out in the form of habituation of children arriving at school until they return home. There are several substances of habituation activities, namely acceptance, constructing good character, religious knowledge, and religious competence or behavior.

Religion and morals are universal values based on the standard of right or wrong, good or bad, most of which are outlined in religious norms created by God Almighty. The habituation that is always used as the norm for religious and moral development is an activity of compassion for the conservation of nature, human beings, and respect for God. In watching cartoons, there are also habits to develop moral and religious values, such as the Upin and Ipin cartoons containing the values of honesty, tolerance, cooperation, caring for others, responsibility, self-discipline, and democracy (Nurwita, 2019).

The structure of the formation of religious and moral values starts from correct knowledge, positive attitude values, and accurate skills towards religious and moral objects. The formation of religious and moral values needs to be done from an early age as a basis for behavior in the next life (Ananda, 2017). A person's level of moral development can generate motivation to make the same response, for different reasons, and interpret the same situation differently (Namee, 1977). Moral development in childhood is a central aspect. From the socialization, it was found that several groups of students with various levels of moral competence were considered as the contents of the zone of proximal development (Molchanov, 2013).

Moral education must be based on an understanding of development, and the development of faith follows a parallel sequence and has a relationship between the two things (Kohlberg, 1974). Kohlberg's approach has proven the basic theoretical and heuristic value of moral education and is seen as the relevance of theory to moral education in the classroom (ísaksson, 1979). The summary of the ideas of proximal development is extended to the domain of moral education (Tappan, 1998). The role of teachers in moral and affective education in schools requires the renewal of educational practices in an era of rapid change (Velea \& Farca, 2013). Several practical ways to improve moral competence suggested through school-based programs, are based on the developmental phase of each individual in a relatively long time (Lau \& Wu, 2012).

Moral education is very urgent to continue to be encouraged through effective moral education in early childhood (Sesmiarni, 2019). Families with a bachelor's educational background are relatively very good at cultivating adolescent moral values (Dedih, 2019). Parents' awareness of protecting adolescents has implications for the involvement of adolescents from agents of moral decline (Rashid et al., 2014). A universal solution for modifying and controlling human behavior, which is pragmatic and conducive, is proposed through the conceptualization of theories and concepts of morality (Wickramasinghe, 2017).

There are three levels of moral development based on cognitive development, based on individual responses to questions about moral dilemmas so that children can develop a sense of right or wrong (Mishra \& Saxena, 2019). There is a fundamental transition of moral 
function from 2-3 years when children move from prosocial beings to moral beings (Endicott et al., 2003). There are six levels of moral development, namely meaningless information; trying to be comfortable in solitude and enjoying one's activities; trying to do real, right, and good to maintain relationships with other people; think better organize their social life for the better; do all the things for the activity that they are doing; change future outlook with success orientation and gain popularity in the field (Fitriani et al., 2019).

The moral is a set of rules or standards, both oral and written, delivered through teachings or discourses about how humans behave to become better. While ethics is the result of critical thinking about moral views and teachings (Suryana, 2016). Piaget and Kohlberg have significant differences, especially in expanding moral development, but religious values view moral development as equal to the growth of individual knowledge and understanding (Moheghi et al., 2020). The moral is the guidance of good behavior possessed by individuals as morality which is reflected in thoughts, attitudes, and behavior (Suyadi, 2009). Good values are related to objects, both are closely related to the context that is being associated, while that value is capital and final which ends in the internalization of universal values (Darmadi, 2012).

Religion is a system that regulates faith/belief and worship of God Almighty as well as rules relating to the association of humans and humans and their environment. Religious people are expected to be highly ethical, but research shows religion can hinder moral growth, and in many cases, religiosity has hurts moral development (Thomas, 2018). Religious teachings contain a set of norms that can lead humans to a civil society civilization $(\mathrm{O}, \mathrm{S}, 2008)$. The development of religious and moral values in children can be done through the habit of praying and worshiping. This habit can be seen from the attitude and way of interacting with other people, how to dress and look good, attitude and eating habits, and daily behavior. In early childhood, learning is carried out through habituation carried out both outside the classroom and inside the classroom, which reflects effective strategies in managing learning phenomena outside the classroom (Du Plessis, 2019).

Character education through training, mentoring, and learning takes place in the school, family, and community (dormitory) environment (Sukendar, 2019). Early childhood learning does not provide certain play activities, themes, and learning methods that are used to stimulate the safe and moral development of early childhood. Activities that must be used are habituation outside formal learning hours. Moral and religious development activities carried out in the form of daily habituation are stimulated by the storytelling method, especially stories containing moral and religious messages that can be listened to through the role of each character in the story.

The story method is an activity carried out by someone to convey a message, information, or a mere fairy tale that can be done orally or in writing (Winda Gunarti, Lilis Suryani, 2010). The forms of storytelling methods are divided into two, namely storytelling without props and storytelling with props (Dhieni, Nurbiana, 2008). The empathy-based storytelling method is very suitable for correcting the perceptions, reasons, expectations, and values of informants regarding certain phenomena or experiences and allows to map the study area based on certain stories (Wallin et al., 2019).

The application of the storytelling method as an activity to stimulate children's growth and development can improve the religious and moral development of early childhood. Much has been said about the theoretical concepts of moral development, methods/techniques/approaches of moral development, and research results related to moral development, but none specifically examines the influence of storytelling methods on the religious and moral development of early childhood, especially related to Balinese culture. Previous studies have discussed that storytelling methods are widely used as a model to develop language skills (Darmayanti et al., 2017), and some of them discuss their relationship to social-emotional development (Anggraini, 2015). However, not many have discussed in depth the use of the storytelling method in the realm of developing moral religion. Thus, the 
purpose of this study is to examine the effect of the storytelling method on the religious and moral development of early childhood in more depth.

\section{METHOD}

This research was conducted at Cahaya Ananda Preschool, Mataram, using a pre-test post-test one-group design experimental approach. This institution has predominantly Hindu students. The instrument used to collect data on the development of religion and morals is an observation guide consisting of four aspects, namely: getting to know daily worship activities; perform daily worship activities with adult guidance; behave according to the teachings of their religion; demonstrate polite behavior as a reflection of noble character. Each instrument item contains four choices according to the Likert scale, namely Undeveloped: if the child does it must be with guidance or an example by the teacher; Begins to Develop: if the child does it still has to be reminded or assisted by the teacher; Developed According to expectations, if the child can do it independently and consistently without having to be reminded or exemplified by the teacher; and Developing Very Good if the child can do it independently and has been able to help his friend who has not achieved the ability according to the expected indicators. The measurement of religious and moral development was carried out twice, pre-test and post-test with 52 children divided into classes B1, B2, and B3. Observational data were transformed into percentage data, which was then analyzed using the t-test technique, namely the difference test between the results of the pre-test and the post-test. The test criteria used a significance level of $5 \%$ and a two-score test. The research chart can be seen in Figure 1.

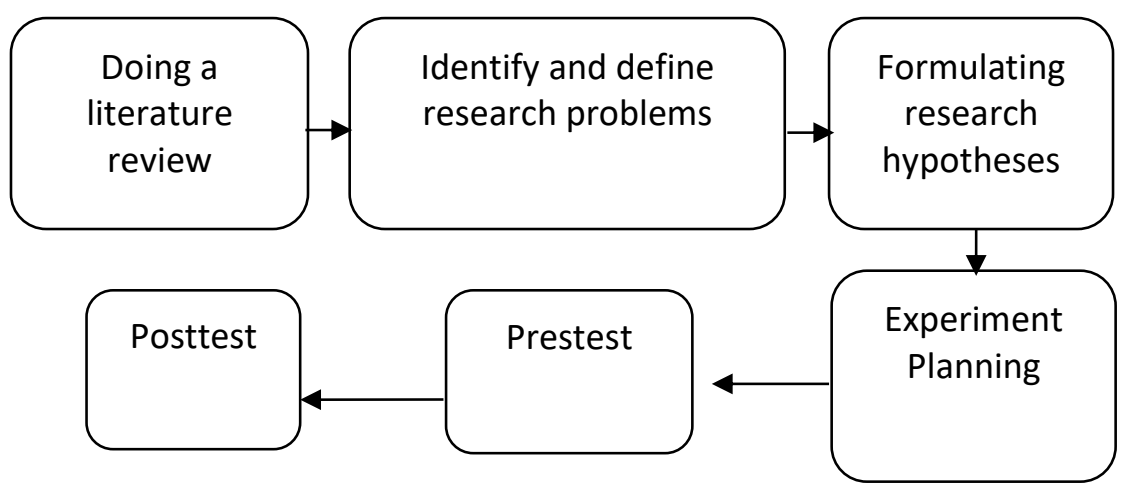

Figure 1. Experimental research stages

\section{RESULT AND DISCUSSION}

Data on the implementation of learning applies the storytelling method with three steps, namely introduction with indicators: preparing facilities and infrastructure, preparing children, learning tools and doing apperception; core activities consisting of; pre-playing steps consisting of several indicators: conveying objectives, a summary of the material, methods used, and assessment of learning outcomes and game steps; foothold during play: divide groups into three according to three types of games (group 1 plays hand puppets, group 2 plays with storybooks, group 3 plays with panelboards). Each group will be rolled after 20 minutes. The first playing activity group 1 carried out activities at table 1 , group 2 at table 2 , and group 3 at table 3 . After the first 20 minutes, the group moved, group 1 to table 2, group 2 to table 3 , and group 3 to table 1 . After 20 minutes the two groups moved again: group 1 to table 3, group 2 to table 1, and group 3 to table 2 . After 20 minutes the three activities ended; foothold after playing: tidying up the playing tools, and carrying out assessments; closing activities consisting of re-disclosure of learning/recalling activities. Learning activities are carried out for 15 effective days, according to the learning schedule for the theme of my family and my environment. 
The instrument for collecting data on religious and moral growth and development variables consists of 4 aspects, namely knowing daily worship activities; Carry out daily worship activities with adult guidance; Behave according to the teachings of their religion; Demonstrate polite behavior as a reflection of noble character. The measurement results found that the most prominent aspect was to behave politely as a reflection of noble character. The average pre-test score $=43.46(36.21 \%)$ and the post-test average $=50.08(41.73 \%)$, an increase of $5.52 \%$. Furthermore, the hypothesis testing of the difference between the pre-test and posttest scores was carried out using SPSS 16.0. The results of the analysis can be presented in the Table 1.

Table 1. Homogeneity test

\begin{tabular}{lcc}
\hline Homogeneity of variance & & \\
\hline Religion and Moral Growth & & Sig. \\
of the children of Cahaya & F & .344 \\
Ananda Preschool, Mataram & .905 & \\
\hline
\end{tabular}

The results of the homogeneity test concluded that the pre-test and post-test data variants did not have a homogeneous variant. The data can be analyzed using parametric statistics testing the difference between two average numbers using a t-test.

Table 2. The result of $t$-test

\begin{tabular}{lccc}
\hline & $\mathrm{t}$ & $\mathrm{df}$ & Sig. (2-tailed) \\
\hline $\begin{array}{l}\text { Religion and Moral Growth of the children of } \\
\text { Cahaya Ananda Preschool, Mataram }\end{array}$ & -4.413 & 102 & .000 \\
\hline
\end{tabular}

The results of the analysis found that the difference between the pre-test and post-test scores was significant. From the data obtained, it can be concluded that there is an influence of the storytelling method on the religious and moral development of early childhood.

\section{Discussion}

Learning activities using the storytelling method on the theme of my family and my environment were carried out four times, namely the sub-themes of my family environment, schools, holy places, and the natural environment (animals). The implementation of learning uses the same structure and steps for each lesson, which is formulated in the daily learning implementation plan. The steps of learning in Early Childhood Education are built-in more detail than learning in higher schools. The first step starts from accepting children in front of the school and before entering class, initial activities, core learning activities, closing activities, which end with recalling activities. The implementation of learning carried out in four experimental activities has been carried out well.

Early childhood learning develops 3 areas, namely knowledge, values/attitudes, and skills which are further elaborated into six phases of early childhood development, namely physical-motor, cognitive, language, socio-emotional, art, and religion or morality. This study focuses more on religious and moral development by the educational vision of the Cahaya Ananda Mataram Preschool, namely a school based on the development of motor intelligence, logico-mathematics, and Hindu religion/morality. Child development is based on the Tri Hita Karana philosophy, which is to build intelligent, independent, mature human beings who are responsible as God's creation, members of society and part of nature. Education has a goal to develop students into individuals who have a harmonious relationship with God, fellow humans and nature (Rasmini et al., 2018). Tri hita karana is the value of truth that teaches children to be able to maintain their balance with each other (tat twamasi, vasudewa kuntumbakam/ brotherhood in one humanity); teach the truth in maintaining a balance with 
the natural environment, not being damaged by nature with plastic waste; teach also how to maintain balance with God through His creation.

Permendikbud (2014) which contains the 2013 Curriculum for Early Childhood Education, the fourth article in the first paragraph states that the achievement of child development at the end of service aged six years is formulated in an integrated manner in the form of four core competencies, namely the first Core Competence on spiritual attitudes, the second Core Competence on attitudes social skills, the third Core Competence on knowledge, and the fourth Core Competence on skills. The four Core Competencies are described in Basic Competencies and Indicators as learning objectives. The structure of the Early Childhood Education curriculum includes programs for the development of religious and moral values, physical-motor, cognitive, language, socio-emotional and artistic. Especially for the program for developing religious and moral values, it includes the realization of a learning atmosphere for the development of good behavior that comes from religious and moral values as well as community life in the context of playing. Teachers and school environment factors, in general, affect children's independence in learning (Humble \& Dixon, 2017). In teaching storytelling, the teacher plays a very important role so that the messages contained in the story can be understood and implemented in their interactions with children.

Growth and development in religious and moral aspects are mostly carried out in habituation activities, such as values of belief in the existence of God, prayer activities, good behavior based on individual and group standards, and respect for parents and other adults (Amelia et al., 2013). Research findings at Cahaya Ananda Preschool Mataram, habituation activities for inculcating religious and moral values are mostly carried out before core learning activities, such as starting from welcoming until before entering class, habituation activities are carried out to say Hindu religious greetings, morning prayers accompanied by chanting mantras. Gayatri. This joint meal activity is carried out to develop the moral value of cooperation, respect for others, independence, responsibility, honesty, and to build good character.

Religious and moral learning is carried out as a supplement to knowledge and skill learning activities as the achievement of the first Core Competence and the second Core Competence, namely spiritual attitudes and social attitudes, is carried out in learning knowledge of the third Core Competence and fourth Core Competence skills. Formally in structured learning in almost all the themes of the eleven themes in Early Childhood Education, religious and moral values can be developed for children. In informal learning activities, especially in the steps of accepting children and preparing for class, resting and eating activities, and releasing children from school, many activities can be carried out that support the growth and development of religious and moral values. Habituation activities carried out since the beginning of the child's attendance at school, and during core activities and other activities that support learning activities are always inserted with religious and moral development activities as well as social attitudes as an effort to develop good character in children. Cultivating character values through habituation (Sukendar et al., 2019)

Early childhood education in general and research sites in particular, it is obligatory to assess children's growth and development in six phases of religious and moral development, physical-motor, cognitive, language, socio-emotional, and artistic. In the realm of Bloom's learning, the six phases of development are also built into three, namely values and attitudes, knowledge and skills. To measure the value or attitude of students used observation techniques with rubric instruments, such as holistic rubrics, analytic, and perception scales. The results of the assessment of religious and moral development for early childhood are standardized in four scales, namely Undeveloped, meaning that the development of children's religious and moral values has not been realized even though it is facilitated by the teacher. Starting to develop, the religious and moral development of children only appears if it is facilitated by the teacher. Developing according to expectations, children's religious and moral values have grown and developed independently according to their age. Very well developed, 
children's religious and moral values have developed independently according to age and can facilitate other friends in learning and playing for the development of religious and moral values.

The results of this study found that learning to tell stories can increase children's religious and moral values. The stories used are animal stories such as Deer, a proud child, Bawang Merah, Bawang Putih, The King of the Jungle. The implementation of storytelling learning uses tools, hand puppets, panelboards, storybooks, and pictures. In principle, all types of stories have a certain role in which generally greed and arrogance will result in harm, while an attitude of humility, helping, and doing good to others results in goodness and happiness. All the contents of the story describe the slogans of rafting upstream, swimming to the edge, namely getting sick first, having fun later. Storytelling activities can develop various aspects of children's development (Yofita, 2013). Learning to use the storytelling method can develop a sense of pride and confidence in children. The influence of various factors which cognitive, numerical, and language skills on the early numeric performance skills of kindergarten children (Aunio et al., 2019).

Pavlov's learning theory presented by Olson (2010) that punishment can reduce the quality of negative behavior and rewards can increase the quality of positive behavior. Giving punishment creates a sense of regret so that it does not repeat negative behavior, while it creates a sense of pride and tends to increase positive behavior. Religious and moral learning through habituation is very good if an educational tool is applied in the form of punishment and reward.

In social learning theory, learning is an interaction between individuals in groups where the subject of students is modeled on educators, very relevant to learning storytelling in Early Childhood Education (Hutchinson \& Waters, 2010). The story scenes depict positive and negative behavioral models to be imitated or avoided so that children can develop a social cognitive framework from the set of values from the adoption of positive models. Bandura's learning theory in children's moral development, such as the concept of a favorable comparison, is useful for maintaining moral emotional stability. If a child violates morals and later in a story finds a more immoral role than he did, then this event can relieve feelings of guilt temporarily (advantageous comparison).

Children's growth and development always face situations that are contrary to religious and moral values, so self-reference about religious and moral values considers this behavior to be wrong. This is studied using the advantageous comparison theory, namely, a favorable comparison can relieve guilt so that children can increase motivation to correct mistakes in achieving behavior that avoids moral mistakes. An automatic experience is an event that is never forgotten not to be repeated in tomorrow's life. Cultivating children with courageous souls including the courage to accept risks and solve problems in life and life has a mantra (Jendra, 2009).

Om advesha sarva bhutanam, maitra karuna eva cha, nirmano mirahamkara, sama sukha dukha ksami.

It means, worshiping God, hopefully not hating all human beings, not feeling possessive and egotistical, friendly and loving, equal to joy and sorrow, and full of forgiving.

One of the religious and moral teachings requires that every human being does not have the nature of revenge either against oneself, others or society so that the buds of religious and moral growth and development are not informative because of guilt barriers in past behavior. In this case, there is the concept of mulat sarira, to realize wise children, live long, prosperous, loving, and friendly to all creatures, not egocentric, emotionally stable, harmonious, and forgiving.

The concept of Ahimsa in human growth and development does not hurt the feelings of others through thoughts, words, and behavior. This is relevant to the concept of education 
and learning to develop individuals according to their potential through interactions between educators, students, and learning resources to become responsible adults vertically and horizontally (tri hita karana philosophy). (Anandamurti, 1998). The implementation of the tri hita karana concept implies that individuals are born with different natures from other individuals, with their helplessness having obligations as social beings who always need the contributions of others. Love can improve children's morals (Sukodoyo, 2018). This strongly supports the results of early childhood research in improving religion and morals through the storytelling method. Within the individual there is a spark of God in the form of a spirit that gives life to every living creature and its existence is governed by the power of God. As long as humans are allowed to live, the source of material life is in nature which is governed by natural laws called rtam. The circle of human life always boils down to respect and belief in God Almighty, through taking care of oneself, preserving the environment, harmonizing relationships with others, to strengthen belief in the creator.

Kindergarten schools are currently managed and included in the formal education group so that they are required to have curriculum, learning, teachers, assessments, and graduate competency standards as outlined in national education standards (Ananda, 2017; Nafsia et al., 2020; Purnama \& Hidayati, 2020). The development of religion and morals in question occurs in the world of schooling. Moral education means developing patterns of behavior by the will of the community that contains the values of life in society, involving two aspects, namely aspects of values and aspects of real life (Zuriah, 2008).

Character education contained in Hindu religious education is teaching in schools that aims to develop the character and character of students, by living the values and beliefs of the community as moral strength, such as honesty, discipline, cooperation and trustworthiness contained in the affective aspects. Trikaya parisuda is a truth that provides understanding so that humans are honest with themselves, honest with others and honest with God (Samba, 2016). This makes the children always respect themselves, their friends and always pray to God. The teachings of karmapahala in Hinduism provide an understanding that the truth about legal justice if we do good, will get good, but if we do bad we get unbecoming. Early childhood learning is carried out by giving an example if we plant mangoes, we will bear mangoes.

Conceptually, the conditions that cause low early childhood religious and moral development are the limited ability of parents to carry out abstract parenting such as roleplaying, storytelling, and various other types of modeling learning that contain religious and moral values or the development of children's character. Observations of the implementation of learning are very minimal, storytelling learning that contains religious and moral values. Religion, moral growth, and child development should be educated in sweet and harmonious language, using language or language expressions that are harmonious and by the development of talents and stages of toddler life. Moral education must start from individuals who uphold moral values, starting from the family, school and wider community.

The principle of moral learning concerns affective learning which must place students as expected moral actors (Suryana, 2019). They should be allowed to learn physically and mentally through interacting with people and learning resources optimally. Many methods can be used to help to learn the moral development of early childhood. However, the storytelling method makes a positive contribution in improving the religious and moral growth of early childhood.

The application of the storytelling method using hand puppets, standing planel boards, and story books in the game uses environmental themes, especially the family, school and natural environment. The success of the implementation of learning with the storytelling method is very dependent on the skills of the teacher. Teachers need to master the content of the story accurately to be able to portray the role models that occur in the story, so that children internalize the content of the story through emotional social responses. This emotional response is a process of internalizing moral messages in early childhood. 
Bandura with social learning theory states that children's moral development is carried out through interaction with models. In the case of morality, educators usually give examples of moral rules which are then internalized by children into a moral code that determines thoughts and behaviors that will get punished or rewarded. The principle of reporting early childhood learning outcomes is done more with positive statements, so that children get more rewards than punishments. Moral development and the development of religious spiritual attitudes are mostly carried out through habituation, starting from the arrival of children, greetings, positive and educational responses, full understanding of the child's emotional situation. Beginning to enter the class, habits are also carried out concerning the growth and development of religion and early childhood morals.

Based on Kohlberg and Piaget's theory of moral development about children's moral development based on habits, both habituation occurs in families and educational institutions, the quality of interaction between educators and children will determine the moral development of children. In learning activities, character development is carried out, honesty, cooperation, responsibility as a supporter of good character is carried out. During eating and resting activities, children internalize more about gratitude for God's power as creator, preserver and fuser of nature.

\section{CONCLUSION}

Based on hypothesis testing, it was found that there was a positive effect of the application of the storytelling method on the religious and moral growth of early childhood. The application of the storytelling learning method requires media, learning resources, and typical learning tools as well as certain themes according to the type and storyline used as learning media. The development of religion and morals of early childhood descriptively has increased from before and after the application of learning using the storytelling method, from the average began to develop as expected.

\section{ACKNOWLEDGEMENT}

This research and scientific work can be completed properly thanks to the participation and assistance of various parties, so on this occasion it is necessary to express gratitude to the leadership of the Gde Pudja Mataram State Hindu High School for providing funds as stimulation of scientific research. Principals, teachers, and administrative staff at Cahaya Ananda Preschool Mataram, Indonesia for providing opportunities for research, assisting in data collection and validating data. All children who have carried out their obligations as research subjects in this experimental study. The research reviewers and friends of the same profession as well as the entire community who have succeeded in writing this scientific paper, may all their deeds of worship be accepted by God Almighty as a dedication to Him.

\section{REFERENCES}

Amelia, N., Ali, M., \& Miranda, D. (2013). Peningkatan Aspek Perkembangan Nilai Agama dan Moral Anak Usia 5-6 Tahun TK Al-Ikhlas Ketapang. Jurnal Pendidikan Dan Pembelajaran Untan, 2(8).

Ananda, R. (2017). Implementasi Nilai-nilai Moral dan Agama pada Anak Usia Dini. Jurnal Obsesi: Jurnal Pendidikan Anak Usia Dini, 1(1), 19-31. https://doi.org/10.31004/obsesi.v1i1.28

Anandamurti, S. S. (1998). Dasar Moralitas Kehidupan Spiritual. Persatuan Ananda Marga Indonesia.

Anggraini, D. D. (2015). Peningkatan Pengembangan Nilai Agama dan Moral Melalui Metode Bercerita. Jurnal PG-PAUD Trunojoyo, 2(2), 76-148.

Aunio, P., Korhonen, J., Ragpot, L., Törmänen, M., Mononen, R., \& Henning, E. (2019). Multifactorial approach to early numeracy-The effects of cognitive skills, language factors and kindergarten attendance on early numeracy performance of South African first 
graders. International Journal of Educational Research, 97(June), 65-76. https://doi.org/10.1016/j.ijer.2019.06.011

Darmadi, H. (2012). Dasar Konsep Pendidikan Moral. Angewandte Chemie International Edition, 6(11), 951-952., 11-31.

Darmayanti, P., Tegeh, I. M., \& Ujianti, R. (2017). Efektivitas Metode Bercerita Dengan Media Boneka Wayang Terhadap Kemampuan Bercakap-Cakap Anak Kelompok B Di Tk Widya Sesana Sangsit 2016/2017. E-Journal Pendidikan Anak Usia Dini Universitas Pendidikan Ganesha Jurusan Pendidikan Guru Pendidikan Anak Usia Dini, 5(3), 336347.

Dedih, U. (2019). Adolescent Moral Development in Families. Jurnal Pendidikan Islam, 4(2), 63-76. https://doi.org/10.15575/jpi.v4i2.2313

Dhieni, Nurbiana, D. (2008). Metode Pengembangan Bahasa. Universitas Terbuka.

Du Plessis, A. E. (2019). Barriers to effective management of diversity in classroom contexts: The out-of-field teaching phenomenon. International Journal of Educational Research, 93, 136-152. https://doi.org/10.1016/j.ijer.2018.11.002

Endicott, L., Bock, T., \& Narvaez, D. (2003). Moral reasoning, intercultural development, and multicultural experiences: Relations and cognitive underpinnings. International Journal of Intercultural Relations, 27(4), 403-419. https://doi.org/10.1016/S0147$\underline{1767(03) 00030-0}$

Fitriani, R., Natsir, M., \& Lubis, I. S. (2019). The Moral Development of the Main Character Sebastian Wilder Portrayed in La La Land Movie (2016). Ilmu Budaya, 3(1), 92-98.

Humble, S., \& Dixon, P. (2017). The effects of schooling, family and poverty on children's attainment, potential and confidence-Evidence from Kinondoni, Dar es Salaam, Tanzania. International Journal of Educational Research, 83, 94-106. https:// doi.org/10.1016/j.ijer.2017.03.001

Hutchinson, T., \& Waters, A. (2010). Theories of learning. In English for Specific Purposes (ketujuh, pp. 39-52). Kencana Prenada Media Group. https:// doi.org/10.1017/CBO9780511733031.009

ísaksson, A. (1979). Kohlberg's Theory of Moral Development and Its Relevance to Education. Scandinavian Journal of Educational Research, 23(2), 47-63. https:// doi.org/10.1080/0031383790230202

Jendra, I. W. (2009). Memohon dan Mendidik Putra Suputra Berdasarkan Budi Pekerti dengan Bahasa yang Harmonis. PANAKOM Publishing.

Kohlberg, L. (1974). Education, Moral Development and Faith. Journal of Moral Education, 4(1), 5-16. https:// doi.org/10.1080/0305724740040102

Lau, P. S. Y., \& Wu, F. K. Y. (2012). Emotional competence as a positive youth development construct: A conceptual review. In Positive Youth Development: Theory, Research and Application (Vol. 2012, Issue i, pp. 39-51). https:// doi.org/10.1100/2012/590163

Mishra, P., \& Saxena, V. (2019). Domains of Learning and Kohlberg ' s Theory of Moral Development. 8(7), 2018-2019.

Moheghi, M., Ghorbanzadeh, M., \& Abedi, J. (2020). The Investigation and Criticism Moral Development Ideas of Kohlberg, Piaget and Gilligan. International Journal of Multicultural and Multireligious Understanding, 7(2), 362-374. https://ijmmu.com/index.php/ijmmu/article/view/1516

Molchanov, S. V. (2013). The Moral Development in Childhood. Procedia - Social and Behavioral Sciences, 86, 615-620. https://doi.org/10.1016/j.sbspro.2013.08.623

Nafsia, A., Yufiarti, Y., \& Supena, A. (2020). Pembentukan Karakter Anak melalui Budaya Nalo pada Anak Usia Dini. Jurnal Obsesi : Jurnal Pendidikan Anak Usia Dini, 4(2), 703. https:// doi.org/10.31004/obsesi.v4i2.439

Namee, S. M. (1977). Moral Behaviour, Moral Development and Motivation. Journal of Moral Education, 7(1), 27-31. https://doi.org/10.1080/0305724770070103 https://doi.org/10.1080/0305724770070103 
Nurwita, S. (2019). Analisis Nilai-Nilai Agama dan Moral Anak Usia Dini dalam Tayangan Film Kartun Upin dan Ipin. Jurnal Obsesi : Jurnal Pendidikan Anak Usia Dini, 3(2), 506. https://doi.org/10.31004/obsesi.v3i2.252

O,S, H. (2008). Metode Pengembangan Moral Dan Nilai-Nilai. Universitas Terbuka.

Permendikbud, N. 137 T. 2014. (2014). Tentang Standar PAUD Memuat Standar PAUD dan No 146 Tentang Kurikulum PAUD. Depdikbud.

Purnama, S., \& Hidayati, L. (2020). Pengasuhan Anak Usia Dini dalam Hikayat Indraputra. Jurnal Obsesi: Jurnal Pendidikan Anak Usia Dini, 4(2), 520. https://doi.org/10.31004/obsesi.v4i2.391

Rashid, A. A., Mamat, A., \& Ibrahim, B. (2014). Barriers to Moral Development of Adolescents and Parental Responsibility: The Case of Malay Working Parents. International Journal of Humanities Social Sciences and Education, 1(6), 40-48.

Rasmini, N. W., Wijana, I. N., \& Sumertha, I. W. (2018). Pengasuhan Holistik Berlandaskan Tri Hita Karana Dalam Mengembangkan Karakter Anak Usia Dini Pada Keluarga Hindu. JPUD - Jurnal Pendidikan Usia Dini, 12(1), 118-129. https://doi.org/10.21009//JPUD.121.10

Samba, I. G. (2016). Mengenalkan Hindu Sebagai Satu Budaya-Sikap Dan Perilaku Hidup (A Way Of Life). Yayasan Dajan Rurung.

Sesmiarni, Z. (2019). The Effective Moral Education on Early Childhood As an Effort Against Immoral Culture. Jurnal Obsesi: Jurnal Pendidikan Anak Usia Dini, 3(2), 561. https://doi.org/10.31004/obsesi.v3i2.191

Sukendar, A., Usman, H., \& Jabar, C. S. A. (2019). Teaching-loving-caring (asah-asih-asuh) and semi-military education on character education management. Cakrawala Pendidikan, 38(2), 292-304. https:// doi.org/10.21831/cp.v38i2.24452

Sukodoyo. (2018). Peran Cinta Kasih Guru Sebagai Prediktor Tindakan Moral Siswa Buddhis Smp Di Jawa Tengah. Jurnal Pendidikan Dan Pembelajaran Dasar, Th. XXXVII.

Suryana. (2016). Stimulasi dan Aspek Perkembangan. Prenada Media Group.

Suyadi. (2009). Bimbingan Konsling untuk PAUD. Diva Press.

Tappan, M. B. (1998). Moral education in the zone of proximal development. Journal of Moral Education, 27(2), 141-160. https:// doi.org/10.1080/0305724980270202

Thomas, J. (n.d.). Religion : Helping or Hindering Moral Development. 6(08).

Velea, S., \& Farca, S. (2013). Teacher's Responsibility in Moral and Affective Education of Children. Procedia - Social and Behavioral Sciences, 76, 863-867. https://doi.org/10.1016/j.sbspro.2013.04.221

Wallin, A., Koro-Ljungberg, M., \& Eskola, J. (2019). The method of empathy-based stories. International Journal of Research and Method in Education, 42(5), 525-535. https://doi.org/10.1080/1743727X.2018.1533937

Wickramasinghe, W. A. D. G. (2017). Process Theory of Moral Development. International Journal of Innovative Research and Development, 6(7), 126-132. https://doi.org/10.24940/ijird/2017/v6/i7/JUL17047

Winda Gunarti, Lilis Suryani, A. M. (2010). Metode Pengembangan Perilaku dan Kemampuan Dasar Anak Usia Dini. Universitas Terbuka.

Yofita, A. (2013). Menumbuhkan Kepercayaan Diri Melalui Bercerita. Indeks.

Zuriah, N. (2008). Pendidikan Moral Dan Budi Pekerti Dalam Perspektif Perubahan. In 2. Bumi Aksara. 